\title{
Highly Potent, Water Soluble Benzimidazole Antagonist for Activated $\alpha_{4} \beta_{1}$ Integrin
}

Richard D. Carpenter, ${ }^{\dagger}$ Mirela Andrei, ${ }^{,}$Edmond Y. Lau, ${ }^{\S}$ Felice C. Lightstone, ${ }^{\S}$ Ruiwu Liu, ${ }^{\ddagger}$ Kit S. Lam, ${ }^{,, *}$ MarkJ. Kurth, ${ }^{\dagger *}$

'Department of Chemistry, University of California, Davis, Davis, CA, 95616.

Division of Hematology and Oncology, Department of Internal Medicine, UC Davis Cancer Center, University of California, Davis, Sacramento, CA 95817

${ }^{\S}$ Chemistry, Materials, and Life Sciences Directorate, Lawrence Livermore National Laboratory, 7000 East St., Livermore, CA 94550

kit.lam@ucdmc.ucdavis.edu,mjkurth@ucdavis.edu

Supporting Information Table of Contents

Structures of 2-10

$. \mathrm{S} 2-\mathrm{S} 3$

Experimental Section:

General \& Ab Initio Procedures...........................................................S4

Synthetic Procedures of 20b-e and 12-19.........................................S5-S7

Competitive Inhibition Cell Adhesion Assay...............................................S7

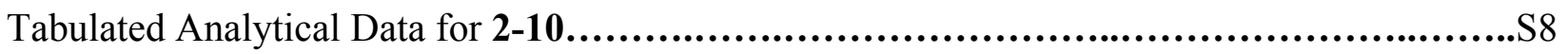

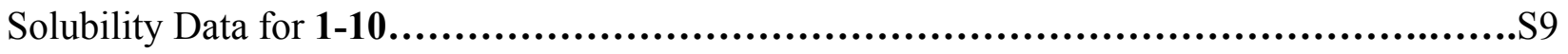

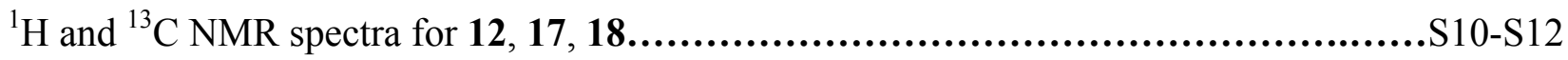

Cell Adhesion Assay Concentration vs. Inhibition Graphs for 1-10........................S13-S17 
Structues of 2-10:
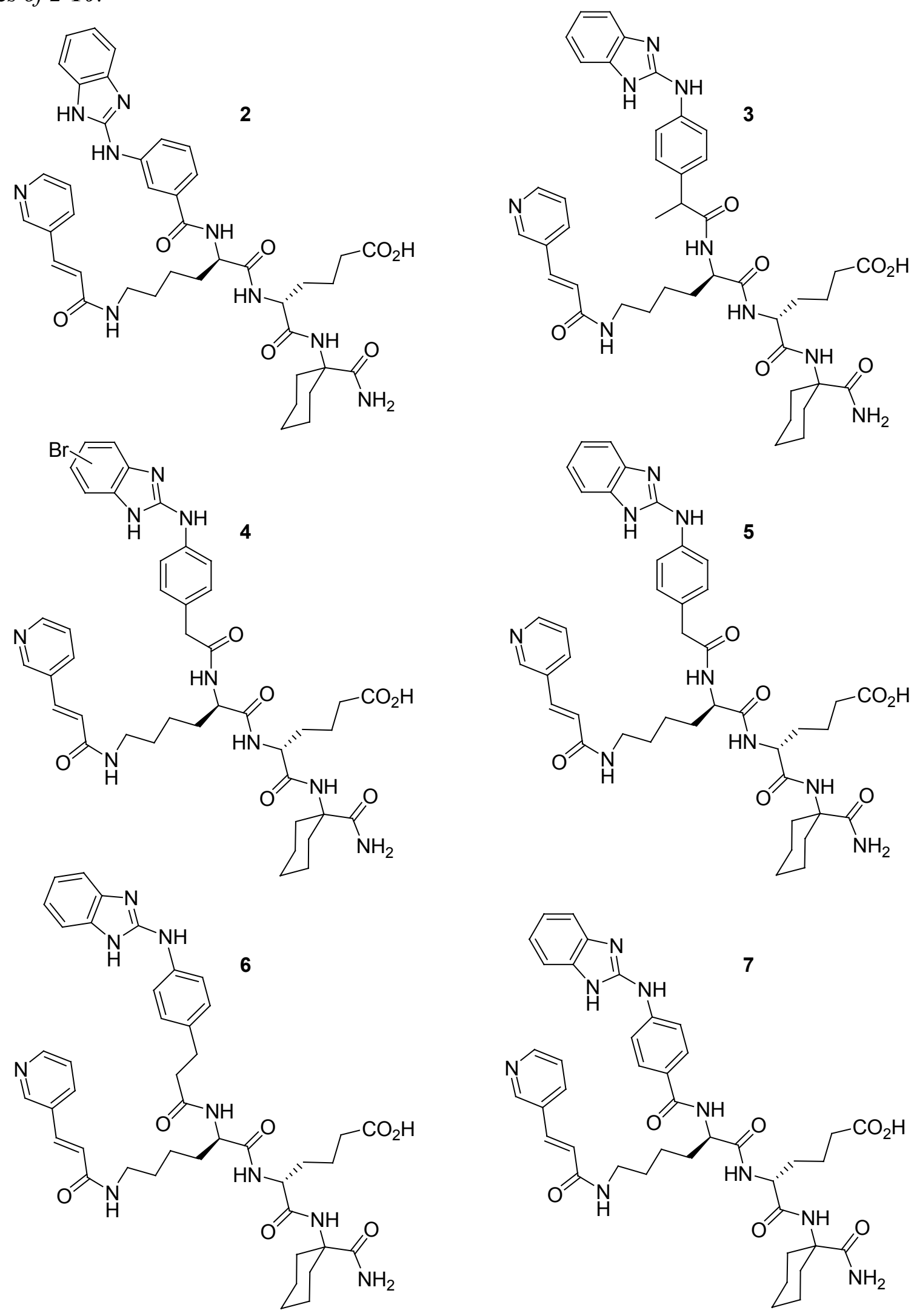

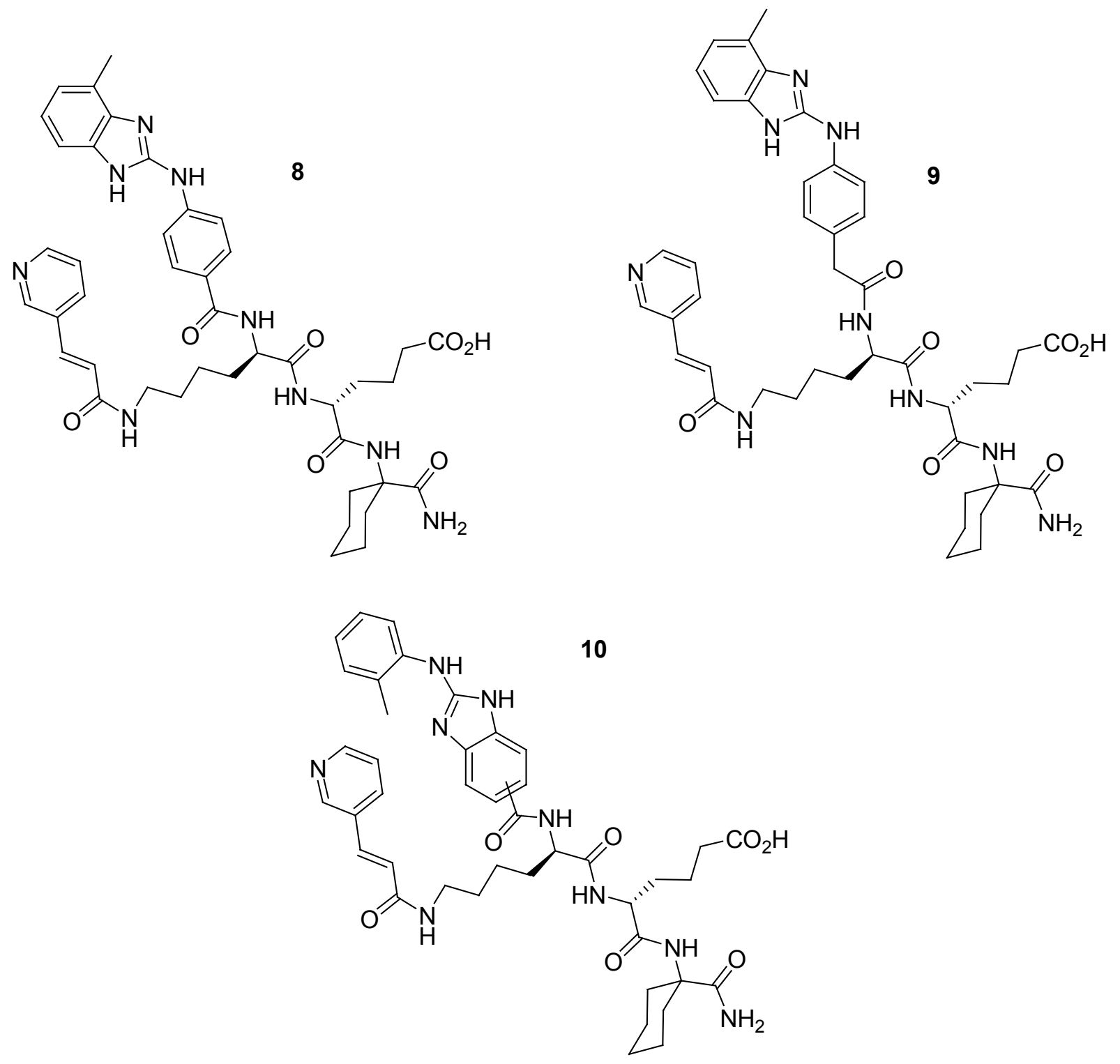
General Synthetic Procedures. All chemicals were purchased from commercial suppliers and used without further purification. Rink amide resin (0.5 mmol/g loading, 100-200 mesh) was purchased from Tianjin Nankai Hecheng Sci \& Tech. Co., Ltd, (batch number GRM-0406-J). Analytical TLC was carried out on pre-coated plates (silica gel 60, F254) and visualized with UV light. NMR spectra $\left({ }^{1} \mathrm{H}\right.$ at 300 $\mathrm{MHz}, 400 \mathrm{MHz}, 600 \mathrm{MHz} ;{ }^{13} \mathrm{C}$ at $75 \mathrm{MHz}, 100 \mathrm{MHz}$ ) were recorded in DMSO- $d_{6}$, methanol- $d_{4}$, and acetone- $d_{6}$ as solvents and chemical shifts are expressed in parts per million relative to TMS. The specifications of the LC/MS are as follows: electrospray (+) ionization, mass range 100-900 Da, $20 \mathrm{~V}$ cone voltage, and $\mathrm{Xterra}^{\circledR} \mathrm{MS} \mathrm{C}_{18}$ column $(2.1 \mathrm{~mm}$ x $50 \mathrm{~mm}$ x $3.5 \mu \mathrm{m})$. CC refers to normal-phase silicagel column chromatography. Concentration refers to rotary evaporation under reduced pressure. After each solid-phase step, the resin was washed by sequential treatment with the following solvents: DMF (2 x $5 \mathrm{~mL}), \mathrm{H}_{2} \mathrm{O}(2 \times 5 \mathrm{~mL}), \mathrm{CH}_{3} \mathrm{OH},(3 \times 5 \mathrm{~mL})$, and $\mathrm{CH}_{2} \mathrm{Cl}_{2}(5 \times 5 \mathrm{~mL})$.

Ab initio calculations. All calculations were performed using the program Gaussian03. ${ }^{1}$ Gas-phase geometries were optimized using density functional theory (DFT) at the B3LYP/6-31G(d) level of theory. ${ }^{2,3}$ Harmonic frequency calculations were performed to ensure the structures were minima. To determine the conformations in solution, the gas-phase conformations were optimized at the B3LYP/6$31 \mathrm{G}(\mathrm{d})$ level of theory and solvation effects (water) were taken into account with the polarizable conductor model (CPCM).

\footnotetext{
${ }^{1}$ Frisch, M. J.; Trucks, G. W.; Schlegel, H. B.; Scuseria, G. E.; Robb, M. A.; Cheeseman, J. R.; Montgomery, Jr., J. A.; Vreven, T.; Kudin, K. N.; Burant, J. C.; Millam, J. M.; Iyengar, S. S.; Tomasi, J.; Barone, V.; Mennucci, B.; Cossi, M.; Scalmani, G.; Rega, N.; Petersson, G. A.; Nakatsuji, H.; Hada, M.; Ehara, M.; Toyota, K.; Fukuda, R.; Hasegawa, J.; Ishida, M.; Nakajima, T.; Honda, Y.; Kitao, O.; Nakai, H.; Klene, M.; Li, X.; Knox, J. E.; Hratchian, H. P.; Cross, J. B.; Adamo, C.; Jaramillo, J.; Gomperts, R.; Stratmann, R. E.; Yazyev, O. A.; Austin, J.; Cammi, R.; Pomelli, C.; Ochterski, J. W.; Ayala, P. Y.; Morokuma, K.; Voth, G. A.; Salvador, P.; Dannenberg, J. J.; Zakrzewski, V. G.; Dapprich, S.; Daniels, A. D.; Strain, M. C.; Farkas, O.; Malick, D. K.; Rabuck, A. D.; Raghavachari, K.; Foresman, J. B.; Ortiz, J. V.; Cui, Q.; Baboul, A. G.; Clifford, S.; Cioslowski, J.; Stefanov, B. B.; Liu, G.; Liashenko, A.; Piskorz, P.; Komaromi, I.; Martin, R. L.; Fox, D. J.; Keith, T.; Al-Laham, M. A.; Peng, C. Y.; Nanayakkara, A.; Challacombe, M.; Gill, P. M. W.; Johnson, B.; Chen, W.; Wong, M. W.; Gonzalez, C.; Pople, J. A.: Gaussian 03. edn Gaussian 03, Revision C. 02. Edited by. Pittsburgh, PA: Gaussian, Inc.; 2004.

2 Becke, A. D. Density-functional thermochemistry. III. The role of exact exchange. J. Chem. Phys. 1993, 98, 5648-5652.

${ }^{3}$ Lee, C.; Yang, W.; Parr, R. G. Development of the Colle-Salvetti correlation-energy formula into a functional of the electron density. Phys. Rev. B. 1988, 37, 785-789.

${ }^{4}$ Barone, V.; Cossi, M. Quantum Calculation of Molecular Energies and Energy Gradients in Solution by a Conductor Solvent Model. $J$. Phys. Chem. A., 1998, 102, 1995-2001.
} 
Ethyl 2-(4-Isothiocyanatophenyl)acetate (20b). Following the General Procedure for Aryl Isothiocyanate Esters (see Experimental Section in manuscript) yielded 20b (5.20 g, 93\%). The analytical data are in accord with literature values. ${ }^{5}$

Methyl 3-(4-Isothiocyanatophenyl)propanoate (20c). Following the General Procedure for Aryl Isothiocyanate Esters yielded 20c (5.41 g, 90\%). The analytical data are in accord with literature values. ${ }^{6}$

Methyl 3-Isothiocyanatobenzoate (20d). Following the General Procedure for Aryl Isothiocyanate Esters yielded 20d (7.06 g, 92\% yield). The analytical data are in accord with literature values. ${ }^{7}$

1-Isothiocyanato-2-methylbenzene (20e). Following the General Procedure for Aryl Isothiocyanate Esters yielded 20e $(7.06 \mathrm{~g}, 92 \%)$. The analytical data are in accord with literature values. ${ }^{8}$

2-(4-(1H-Benzo[d]imidazol-2-ylamino)phenyl)propanoic Acid (12). Following the General Procedure for Benzimidazole Acids yielded 12 (2.05 g, 71\%) as a light brown solid: mp 355-358 ${ }^{0} \mathrm{C}$; IR (neat) 3550 (st, br), 3284 (sh), 3050 (st) 1705 (st); ${ }^{1} \mathrm{H}$ NMR (300 MHz, DMSO-d $)$ : $\delta 7.66$ (d, $J=8.7 \mathrm{~Hz}$, 2H), $7.31(\mathrm{dd}, J=5.7 \mathrm{~Hz}, J=3 \mathrm{~Hz}, 2 \mathrm{H}), 7.23(\mathrm{~d}, J=8.7 \mathrm{~Hz}, 2 \mathrm{H}), 6.99(\mathrm{dd}, J=5.4 \mathrm{~Hz}, J=3 \mathrm{~Hz}, 2 \mathrm{H})$, $3.62(\mathrm{q}, J=7.2 \mathrm{~Hz}, 1 \mathrm{H}), 1.34(\mathrm{~d}, J=6.9 \mathrm{~Hz}, 3 \mathrm{H}) ;{ }^{13} \mathrm{C}$ NMR $\left(75 \mathrm{MHz}, \mathrm{DMSO}-d_{6}\right): \delta 175.7,150.5,139.1$, 136.8, 133.9, 127.9, 127.9, 120.4, 117.7, 112.5, 44.1, 18.6; ESI MS $(m / z) 282(\mathrm{M}+\mathrm{H})^{+}$. Anal. Calcd for $\mathrm{C}_{16} \mathrm{H}_{15} \mathrm{~N}_{3} \mathrm{O}_{2}$ : C, 68.31; H, 5.37; N, 14.94. Found: C, 68.07; H, 5.36; N, 14.42. Purity was determined to be $98 \%$ by HPLC analysis on the basis of absorption at $220 \mathrm{~nm}$.

2-(4-(56-Bromo-1H-benzo[d]imidazol-2-ylamino)phenyl)acetic Acid (13). Following the General Procedure for Benzimidazole Acids yielded 13 (3.31 g, 79\%). The analytical data are in accord with our peviously reported values. ${ }^{9}$

\footnotetext{
5 Sayigh, A. A. R.; Ulrich, H.; Potts. J. S. The Reaction of Arylamines with Diethylthiocarbamoyl Chloride. A New Synthesis of Aryl Isothiocyanates. J. Org. Chem. 1965, 30, 2465-2466.

${ }^{6}$ Browne, D. W.; Dyson. G. W. J. Chem. Soc. 1934, 178-179.

${ }^{7}$ Budesinsky, M.; Exner. O. Correlation of carbon-13 substituent-induced chemical shifts: Meta- and para-substituted methyl benzoates. Magn. Reson. Chem. 1989, 27, 585-591.

${ }^{8}$ Pigula, R.; Krcyczka, K.; Golebiewski, M.; Kazimierczak J. Organika 2003, 11-22.

9 Carpenter, R. D.; DeBredt, P. B.; Lam, K. S.; Kurth, M. J. Carbodiimide-Based Benzimidazole Library Method. J. Comb. Chem. 2006, 8, 907-914.
} 
2-(4-(1H-Benzo[d]imidazol-2-ylamino)phenyl)acetic Acid (14). Following the General Procedure for Benzimidazole Acids yielded 14 (4.82 g, 83\%). The analytical data are in accord with our previously reported values. ${ }^{9}$

3-(4-(1H-Benzo[d]imidazol-2-ylamino)phenyl)propanoic Acid (15). Following the General Procedure for Benzimidazole Acids yielded 15 (1.51 g, 79\%). The analytical data are in accord with our previously reported values. $^{9}$

4-(1H-Benzo $[d]$ imidazol-2-ylamino)benzoic Acid (16). Following the General Procedure for Benzimidazole Acids yielded 16 (2.32 g, 88\%). The analytical data are in accord with literature values. ${ }^{10}$ 4-(4 ${ }^{7}$-Methyl-1H-benzo[d]imidazol-2-ylamino)benzoic Acid (17). Following the General Procedure for Benzimidazole Acids yielded 17 (3.82 g, 82\%) off white solid: mp 375-378 ${ }^{\circ} \mathrm{C}$; IR (neat) 3534 (st, br), 3274 (sh), 3042 (sh), 2992, 1694 (st); ${ }^{1} \mathrm{H}$ NMR (400 MHz, DMSO-d $)$ ): $\delta 12.02$ (br s, $\left.1 \mathrm{H}\right), 7.99$ (d, $J=7.2$ $\mathrm{Hz}, 2 \mathrm{H}), 7.62(\mathrm{~d}, J=7.6 \mathrm{~Hz}, 2 \mathrm{H}), 7.37$ (apparent d, $J=8.4 \mathrm{~Hz}, 1 \mathrm{H}), 7.30$ (apparent s, 1H), 7.07 (apparent $\mathrm{d}, J=8.4 \mathrm{~Hz}, 1 \mathrm{H}) ; 2.37(\mathrm{~s}, 3 \mathrm{H}) ;{ }^{13} \mathrm{C} \mathrm{NMR}\left(100 \mathrm{MHz}, \mathrm{DMSO}-d_{6}\right): \delta 166.8,146.6,141.5,132.9,131.1$, $130.8,128.7,126.3,124.5,124.4,120.0,112.4,21.3$; ESI MS $(m / z) 268(\mathrm{M}+\mathrm{H})^{+}$. Anal. Calcd for $\mathrm{C}_{15} \mathrm{H}_{13} \mathrm{~N}_{3} \mathrm{O}_{2}$ : C, 67.40; H, 4.90; N, 15.72. Found: C, 67.63; H, 4.90; N, 15.78. Purity was determined to be $97 \%$ by HPLC analysis on the basis of absorption at $220 \mathrm{~nm}$.

2-(4-(4 ${ }^{7}$-Methyl-1H-benzo[d] imidazol-2-ylamino)phenyl)acetic Acid (18). Following the General Procedure for Benzimidazole Acids yielded 18 (3.55 g, 84\%) as a light gray solid: $\mathrm{mp} 385-387{ }^{\circ} \mathrm{C}$; IR (neat) 3547 (st, br), 3260 (sh), 3057 (sh), 2981, 1718 (st); ${ }^{1} \mathrm{H}$ NMR (300 MHz, DMSO- $d_{6}$ ): $\delta 13.29$ (br s, 1H), $11.38(\mathrm{~s}, 1 \mathrm{H}), 7.42(\mathrm{~d}, J=8.7 \mathrm{~Hz}, 2 \mathrm{H}), 7.37(\mathrm{~d}, J=8.4 \mathrm{~Hz}, 2 \mathrm{H}), 7.27(\mathrm{~d}, J=7.8 \mathrm{~Hz}, 1 \mathrm{H}), 7.16$ (apparent t, $J=7.8 \mathrm{~Hz}, 1 \mathrm{H}), 7.06(\mathrm{~d}, J=7.2 \mathrm{~Hz}, 1 \mathrm{H}), 3.62,(\mathrm{~s}, 2 \mathrm{H}), 2.49(\mathrm{~s}, 3 \mathrm{H}) ;{ }^{13} \mathrm{C} \mathrm{NMR}(75 \mathrm{MHz}$, DMSO- $\left.d_{6}\right): \delta 163.6,138.9,126.1,123.7,121.8,120.7,119.9,115.7,114.6,113.3,113.0,100.5,31.6,7.7$; ESI MS $(m / z) 282(\mathrm{M}+\mathrm{H})^{+}$. Anal. Calcd for $\mathrm{C}_{16} \mathrm{H}_{15} \mathrm{~N}_{3} \mathrm{O}_{2}$ : C, 68.31; H, 5.37; N, 11.37. Found: C, 68.17;

\footnotetext{
${ }^{10}$ Chandrakumar, N.; Chen, B.B.; Chen, H.; Clare, M.; Gasiecki, A.F.; Haack, R.A.; Malecha, J.W.; Ruminski, P.G.; Russell, M.A. U.S. Patent 5773646 1998; Chem. Abstr. 1998, 72.
} 
H, 5.36; N, 11.34. Purity was determined to be $97 \%$ by HPLC analysis on the basis of absorption at 220 nm.

2-(o-Tolylamino)-1H-benzo[d]imidazole-5 ${ }^{6}$-carboxylic Acid (19). Following the General Procedure for Benzimidazole Acids yielded 19 (2.15 g, 80\%). The analytical data are in accord with our previously reported values. ${ }^{9}$

Competitive Cell Adhesion Assay. Neutravidin $(1 \mu \mathrm{g} / \mathrm{mL})$ was incubated for $1 \mathrm{~h}$ in a 96 -well plate followed by adding $2 \mu \mathrm{M}$ biotinylated CS-1 peptide. The wells were then blocked with $1 \%$ BSA in PBS solution, followed by the addition of $80 \mu \mathrm{L}$ consisting of $1.3 \times 10^{5}$ Molt-4 cells, and finally different dilutions of tested ligands in binding buffer $\left(1 \mathrm{mM}\right.$ of $\mathrm{Mn}^{2+}$ in TBS) were added in triplicate. To allow binding, the plates were incubated for $30 \mathrm{~min}$ at $37^{\circ} \mathrm{C}$, followed by wash removal of unbound cells with PBS. Bound cells were fixed with $10 \%$ formalin buffered in phosphate for $30 \mathrm{~min}$ and stained with $0.1 \%$ crystal violet. After washing and drying at room temperature, the dye was dissolved in $1 \%$ SDS, and absorbance at $570 \mathrm{~nm}$ was measured using a UV/Vis 96-well plate reader. Inhibition was calculated as a percentage resulting from the concentration-dependent curve, and the $\mathrm{IC}_{50}$ data is shown in Table 1 . The $\mathrm{IC}_{50}$ of 1 (LLP2A) was previously reported to be $2 \mathrm{pM}$ with Jurkat cells. ${ }^{11}$ The $\mathrm{IC}_{50}$ value tends to vary somewhat with different batch of cells and the specific cell line used. We used Molt-4 cells, instead of Jurkat cells, for our current binding studies because Molt-4 xenograft can be readily induced in nude mice and therefore will be used in our future in vivo pharmacokinetic and imaging studies. The $\mathrm{IC}_{50}$ of $\mathbf{1}$, in this current study, was determined to be $37 \mathrm{pM}$, and this value will be used for comparison with that of the 2-10 compounds.

\footnotetext{
11 Peng L.; Liu R.; Marik J.; Wang X.; Takada Y.; Lam K. S. Combinatorial chemistry identifies high-affinity peptidomimetics against $\alpha_{4} \beta_{1}$ integrin for in vivo tumor imaging. Nat. Chem. Biol. 2006, 2, 381-389.
} 
Tabulated Analytical Data for 2-10:

\begin{tabular}{|c|c|c|c|c|c|c|c|}
\hline Compound & Yield & Amount & Purity & ESI MS & MALDI HRMS & Anal. Calcd. & Found \\
\hline 2 & $63 \%$ & $29 \mathrm{mg}$ & $100 \%$ & 780 & 780.3835 & $\begin{array}{c}\mathrm{C}, 63.14 ; \mathrm{H}, \\
6.33 ; \mathrm{N}, 16.16\end{array}$ & $\begin{array}{c}\mathrm{C}, 63.31 ; \mathrm{H}, \\
6.34 ; \mathrm{N}, 16.20\end{array}$ \\
\hline 3 & $60 \%$ & $28 \mathrm{mg}$ & $98 \%$ & 808 & 808.4138 & $\begin{array}{c}\mathrm{C}, 63.92 ; \mathrm{H}, \\
6.61 ; \mathrm{N}, 15.60\end{array}$ & $\begin{array}{c}\mathrm{C}, 63.78 ; \mathrm{H} \\
6.59 ; \mathrm{N}, 15.55\end{array}$ \\
\hline 4 & $57 \%$ & $30 \mathrm{mg}$ & $100 \%$ & $\begin{array}{l}872 \\
874\end{array}$ & $\begin{array}{l}872.3103 \\
874.3118\end{array}$ & $\begin{array}{c}\mathrm{C}, 57.80 ; \mathrm{H}, \\
5.77 ; \mathrm{N}, 14.44\end{array}$ & $\begin{array}{c}\mathrm{C}, 57.69 ; \mathrm{H} \\
5.76 ; \mathrm{N}, 14.42\end{array}$ \\
\hline 5 & $62 \%$ & $29 \mathrm{mg}$ & $99 \%$ & 794 & 794.3988 & $\begin{array}{c}\mathrm{C}, 63.54 ; \mathrm{H}, \\
6.47 ; \mathrm{N}, 15.88\end{array}$ & $\begin{array}{c}\mathrm{C}, 63.56 ; \mathrm{H} \\
6.49 ; \mathrm{N}, 15.90\end{array}$ \\
\hline 6 & $71 \%$ & $34 \mathrm{mg}$ & $98 \%$ & 808 & 808.4150 & $\begin{array}{c}\mathrm{C}, 63.92 ; \mathrm{H}, \\
6.61 ; \mathrm{N}, 15.60\end{array}$ & $\begin{array}{c}\mathrm{C}, 63.70 ; \mathrm{H} \\
6.60 ; \mathrm{N}, 15.61\end{array}$ \\
\hline 7 & $64 \%$ & $30 \mathrm{mg}$ & $98 \%$ & 780 & 780.3825 & $\begin{array}{c}\mathrm{C}, 63.14 ; \mathrm{H}, \\
6.33 ; \mathrm{N}, 16.16\end{array}$ & $\begin{array}{c}\mathrm{C}, 63.06 ; \mathrm{H} \\
6.34 ; \mathrm{N}, 16.15\end{array}$ \\
\hline 8 & $59 \%$ & $28 \mathrm{mg}$ & $99 \%$ & 794 & 794.3978 & $\begin{array}{c}\mathrm{C}, 63.54 ; \mathrm{H}, \\
6.47 ; \mathrm{N}, 15.88\end{array}$ & $\begin{array}{c}\mathrm{C} ; 63.48 ; \mathrm{H}, \\
6.47 ; \mathrm{N}, 15.90\end{array}$ \\
\hline 9 & $53 \%$ & $26 \mathrm{mg}$ & $98 \%$ & 808 & 808.4135 & $\begin{array}{c}\mathrm{C}, 63.92 ; \mathrm{H}, \\
6.61 ; \mathrm{N}, 15.60\end{array}$ & $\begin{array}{c}\mathrm{C}, 64.12 ; \mathrm{H} \\
6.61 ; \mathrm{N}, 15.62\end{array}$ \\
\hline 10 & $50 \%$ & $24 \mathrm{mg}$ & $99 \%$ & 794 & 794.3978 & $\begin{array}{c}\mathrm{C}, 63.54 ; \mathrm{H} \\
6.47 ; \mathrm{N}, 15.88\end{array}$ & $\begin{array}{c}\mathrm{C}, 63.41 ; \mathrm{H} \\
6.48 ; \mathrm{N}, 15.87\end{array}$ \\
\hline
\end{tabular}

Table 1. Anayltical data for 2-10: Overall yield, amount, purity (determined by two varying gradient HPLC analyses on the basis of absorption at $220 \mathrm{~nm})$, ESI MS $(\mathrm{M}+\mathrm{H})^{+}$, MALDI HRMS $[\mathrm{M}+\mathrm{H}]^{+}$, as well as calculated and found combustion analyses. 


\begin{tabular}{ccc}
\hline Compound & $\log P$ & $k$ \\
\hline 4-methylamino benzoic acid $^{a}$ & 1.01 & 0.183 \\
salicylic acid $^{a}$ & 2.26 & 0.448 \\
DCC $^{a}$ & 3.33 & 0.679 \\
diclofenac $^{a}$ & 4.51 & 1.168 \\
$\mathbf{1}$ & 3.26 & 0.730 \\
$\mathbf{2}$ & 2.12 & 0.433 \\
$\mathbf{3}$ & 2.63 & 0.580 \\
$\mathbf{4}$ & 1.96 & 0.405 \\
$\mathbf{5}$ & 2.23 & 0.456 \\
$\mathbf{6}$ & 2.80 & 0.610 \\
$\mathbf{7}$ & 1.83 & 0.365 \\
$\mathbf{8}$ & 1.86 & 0.381 \\
$\mathbf{9}$ & 2.58 & 0.566 \\
$\mathbf{1 0}$ & 1.88 & 0.385
\end{tabular}

Table 2. The $\log P$, capacity factor $k$ values for standards ${ }^{a}$ and compounds $1-10$. The capacity factor $k$ equals the difference of the compound retention time $t_{r}$ and the void retention time $t_{o}$ (uracil $t_{o}=4.71 \mathrm{~min}$ ) divided by $t_{0}$. All retention times were measured using reverse-phase HPLC.

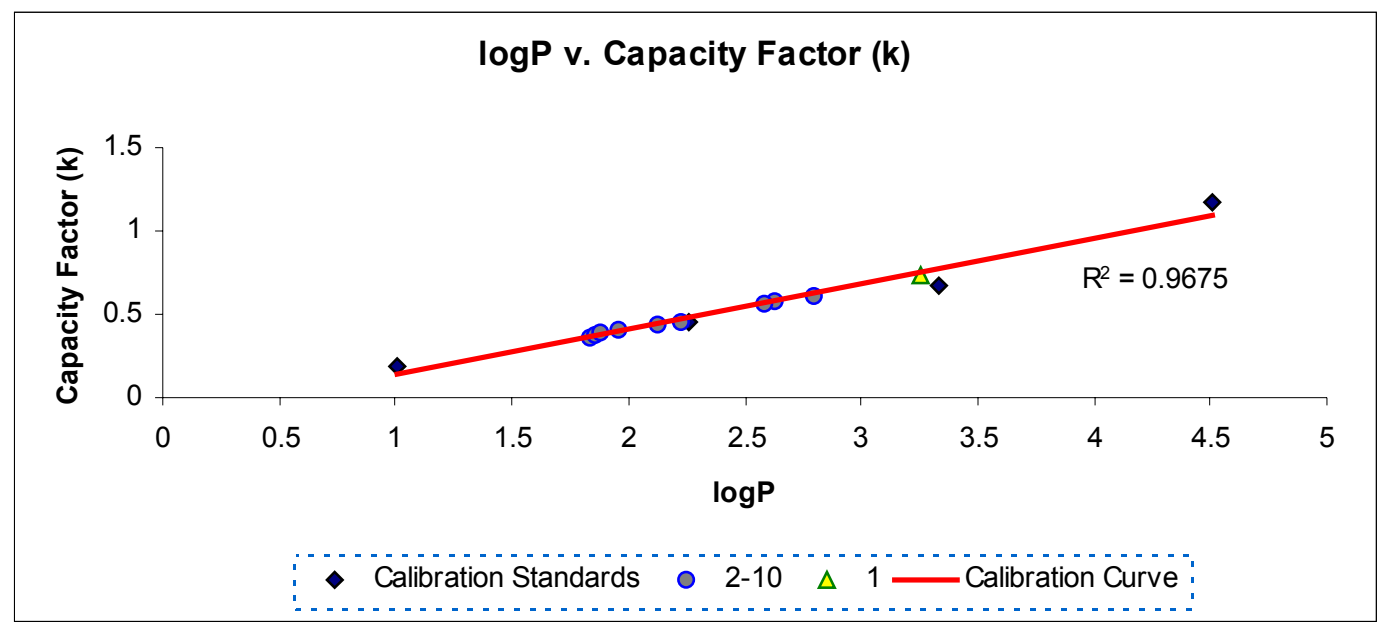

Figure 1. Plot of $\log P$ vs. capacity factor $k$ for standards and compounds 1-10. 
${ }^{1} H$ and ${ }^{13} C$ NMR Spectral Data:
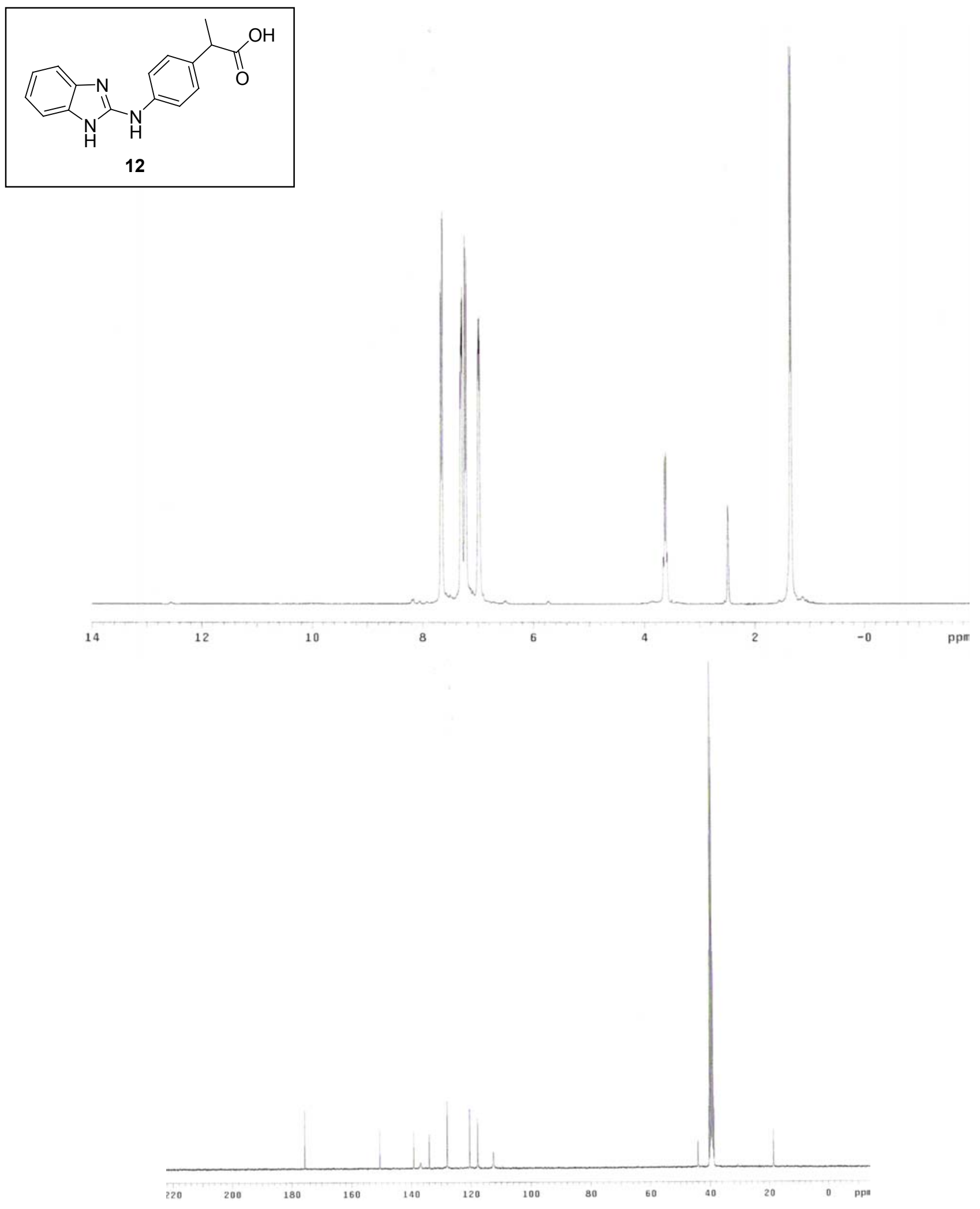

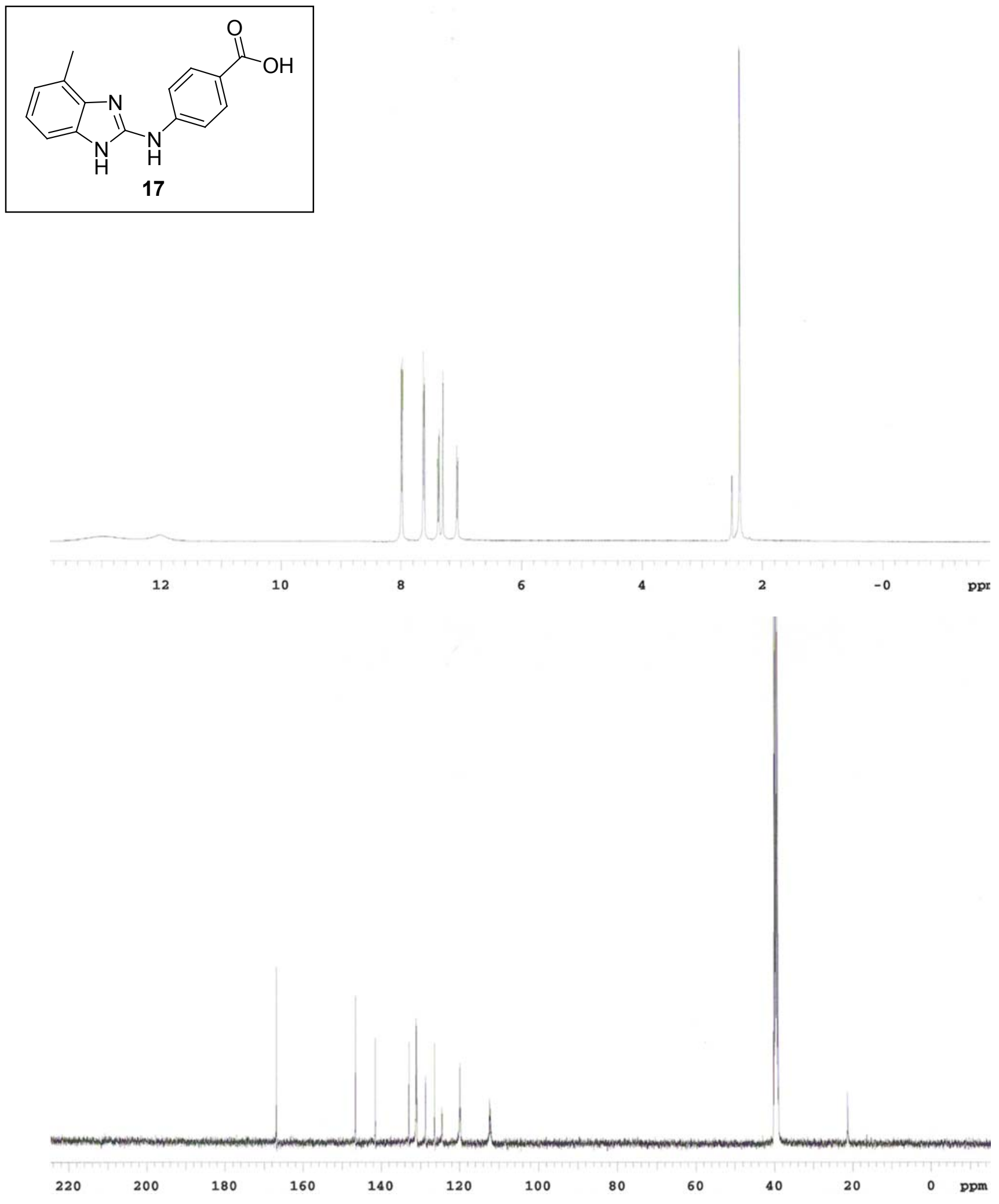

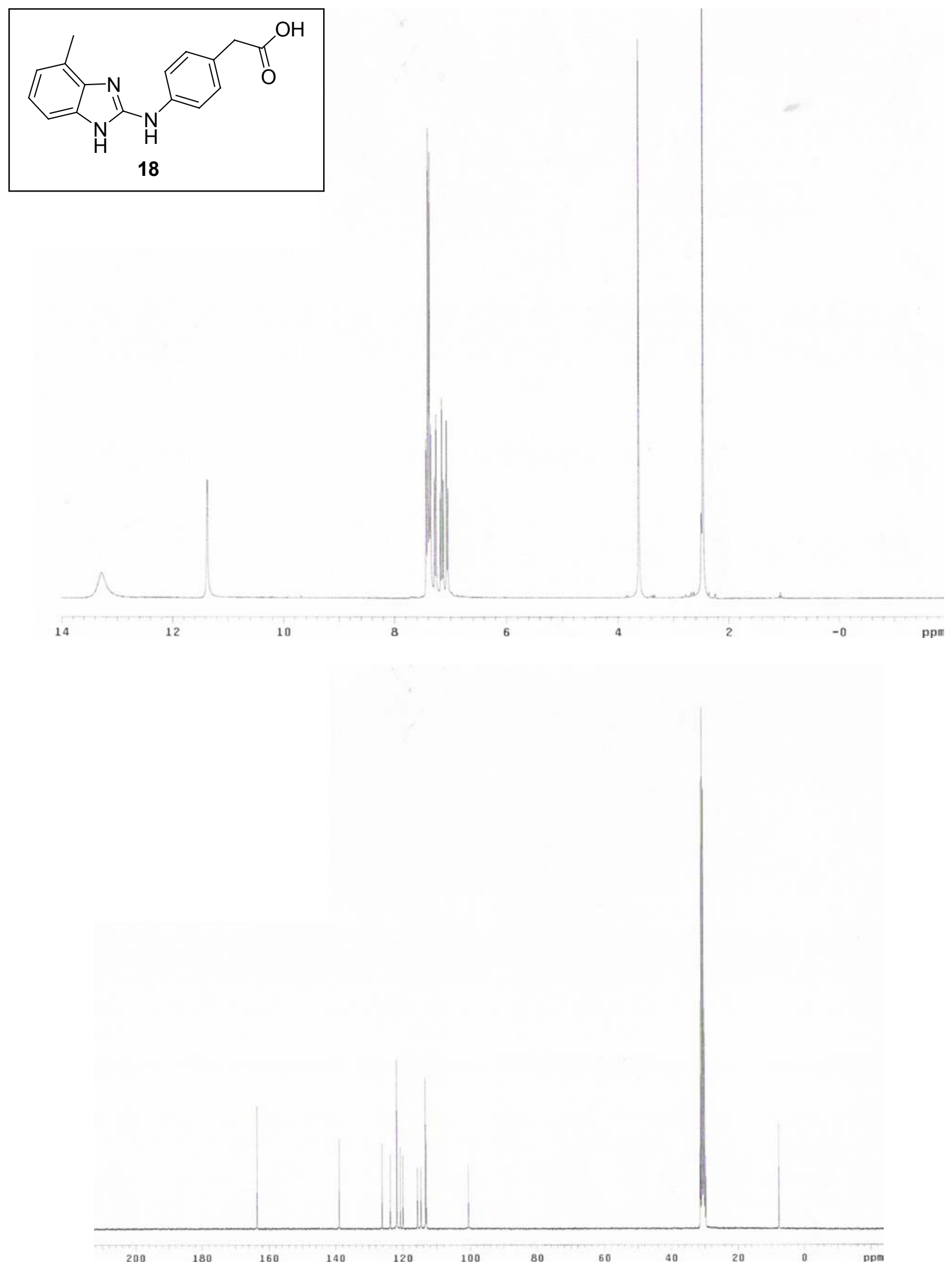
Cell Adhesion Assay Concentration vs. Inhibition Graphs for 1-10<smiles>Cc1ccccc1NC(=O)Nc1ccc(C(=O)NC(CCCCNC(=O)/C=C/c2cccnc2)C(=O)N[C@@H](CCCC(=O)O)C(=O)NC2(C(N)=O)CCCC2)cc1</smiles>

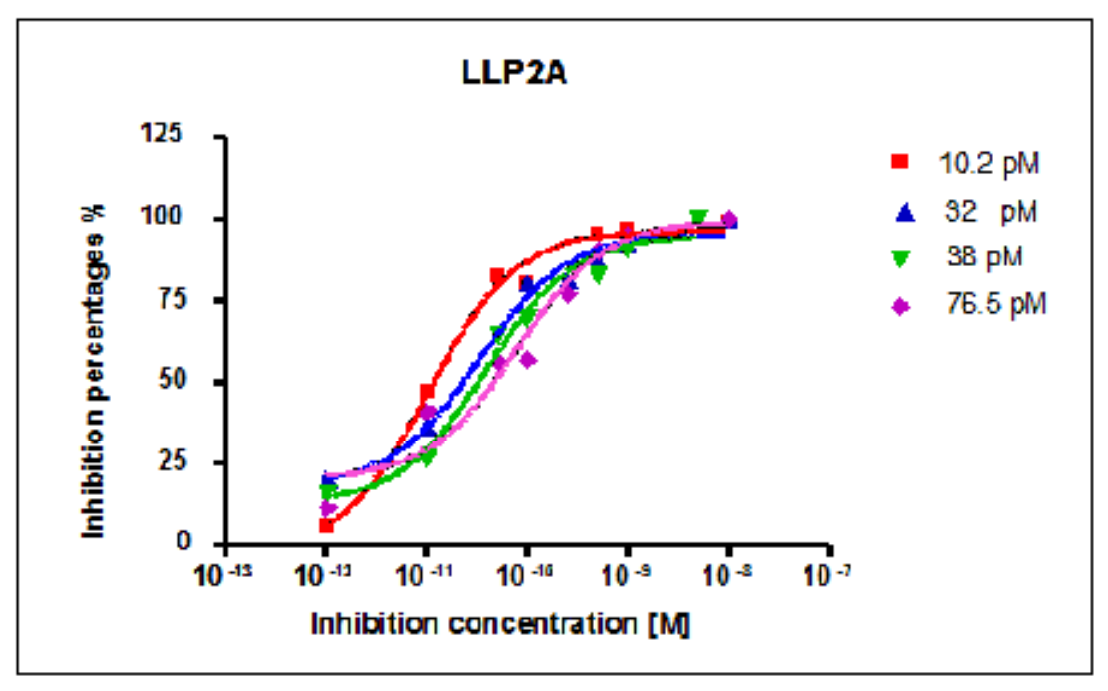

1: $\mathrm{IC}_{50}=37.2 \pm 24.3 \mathrm{pM}$
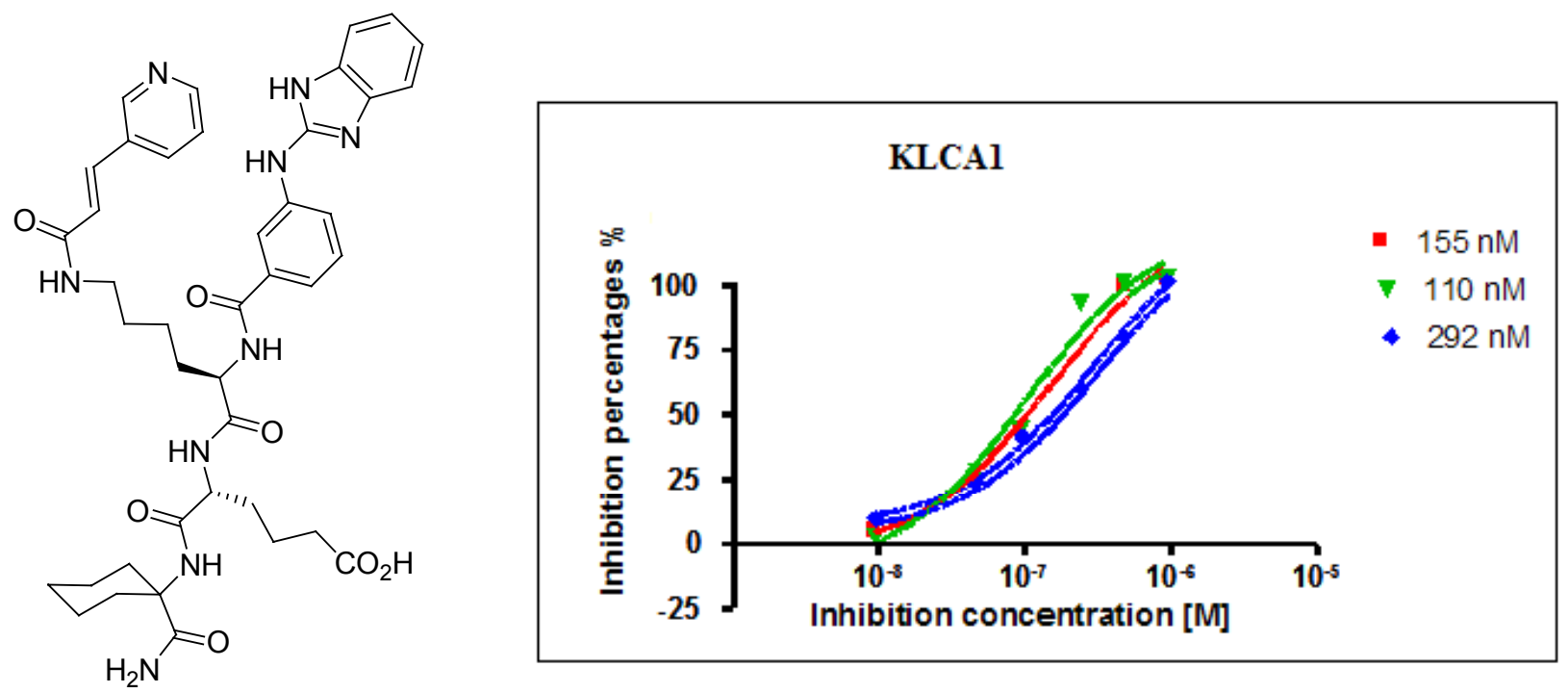

2: $\mathrm{IC}_{50}=185.6 \pm 74.79 \mathrm{nM}$ 

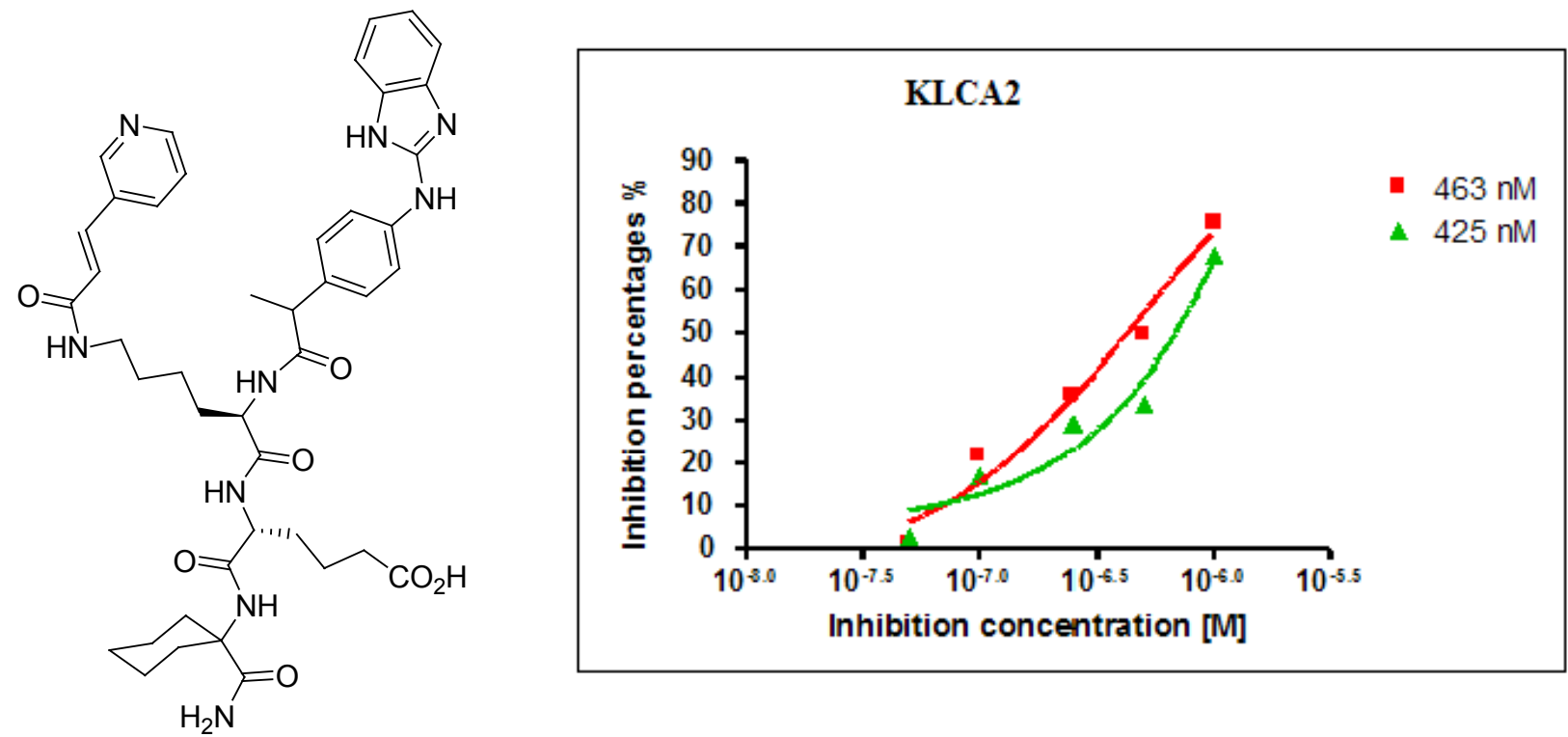

3: $\mathrm{IC}_{50}=444 \pm 26.8 \mathrm{nM}$
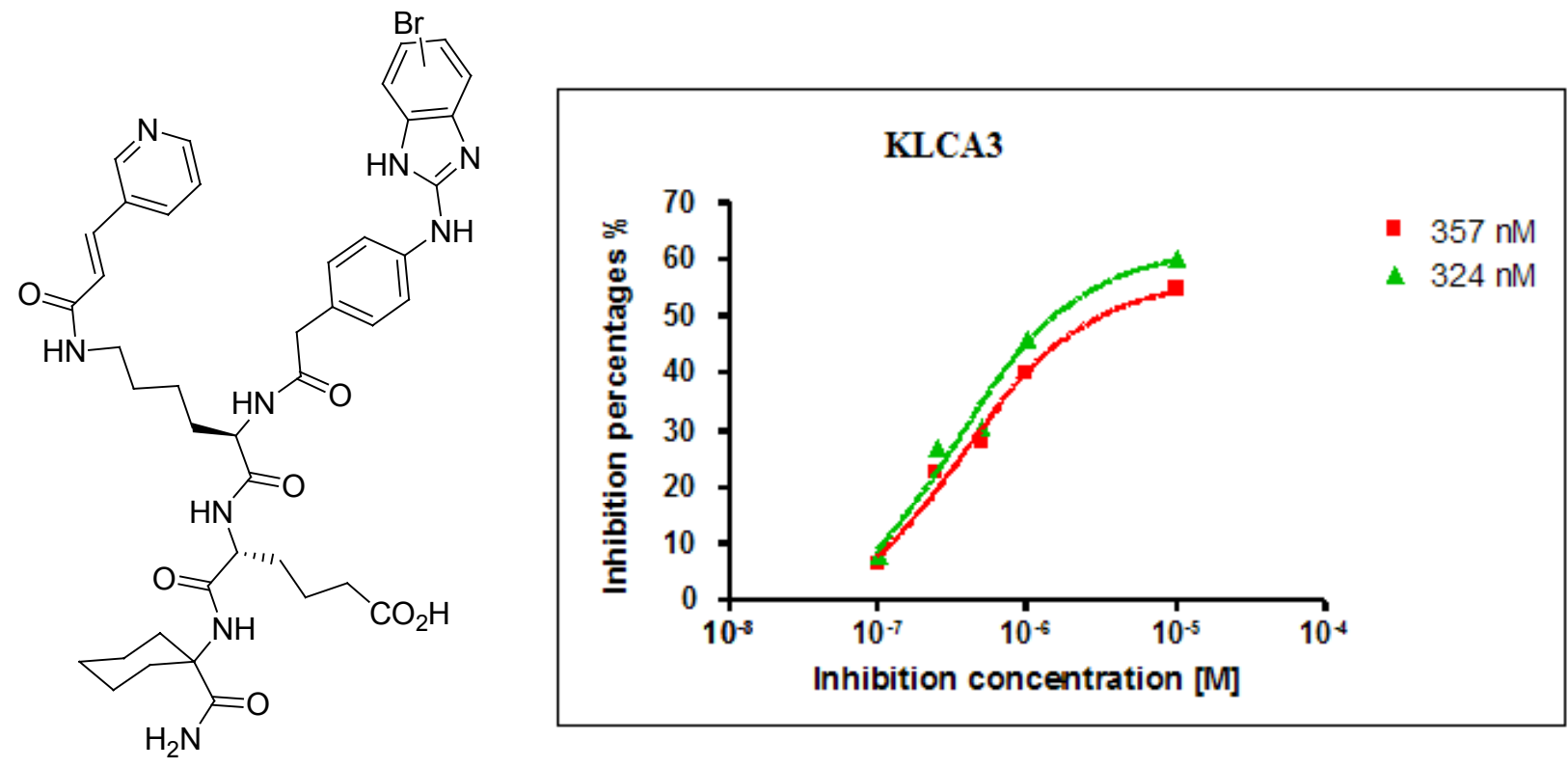

4: $\mathrm{IC}_{50}=340 \pm 23.33 \mathrm{nM}$ 

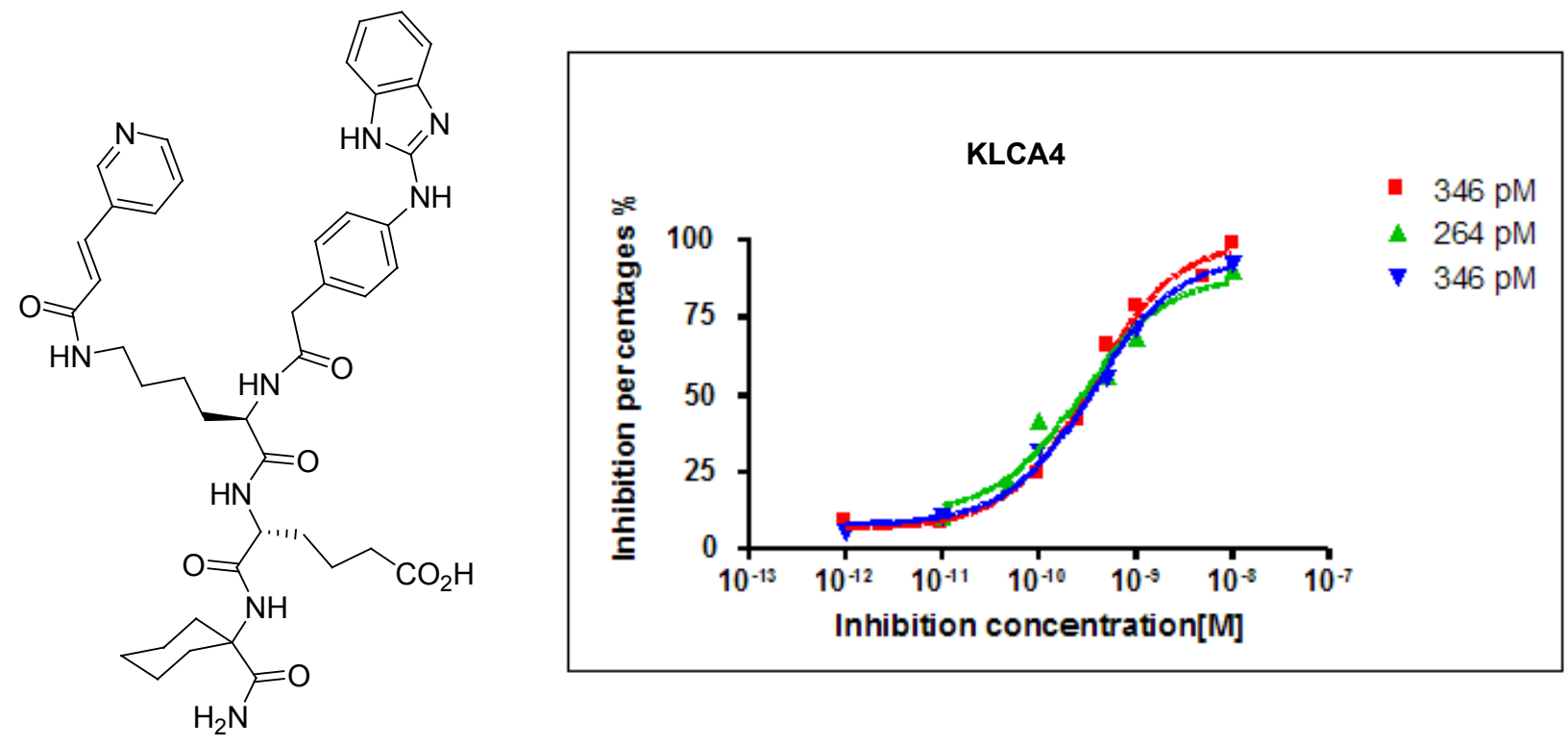

5: $\mathrm{IC}_{50}=305 \pm 58 \mathrm{pM}$
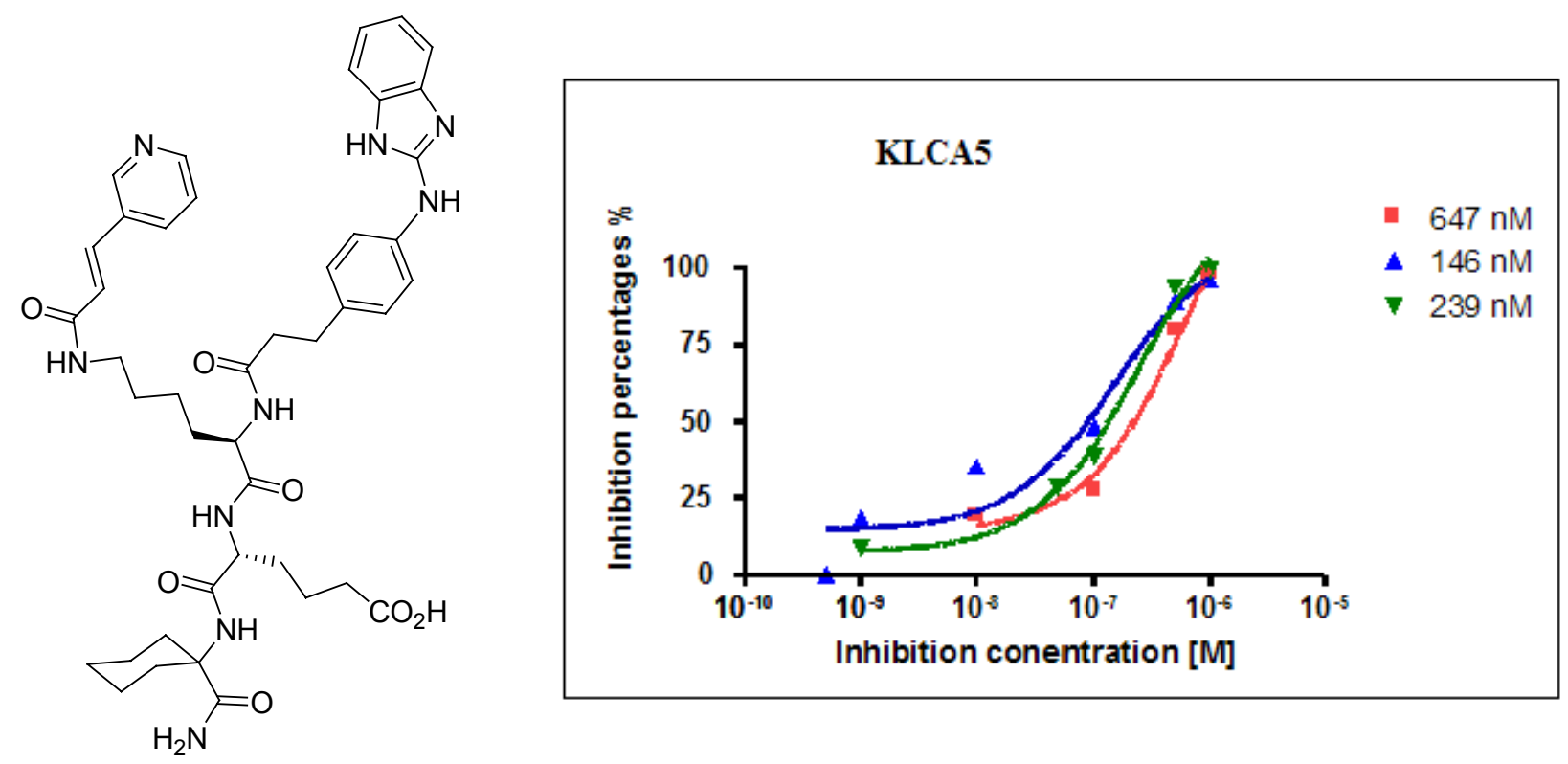

6: $\mathrm{IC}_{50}=344 \pm 266 \mathrm{nM}$ 

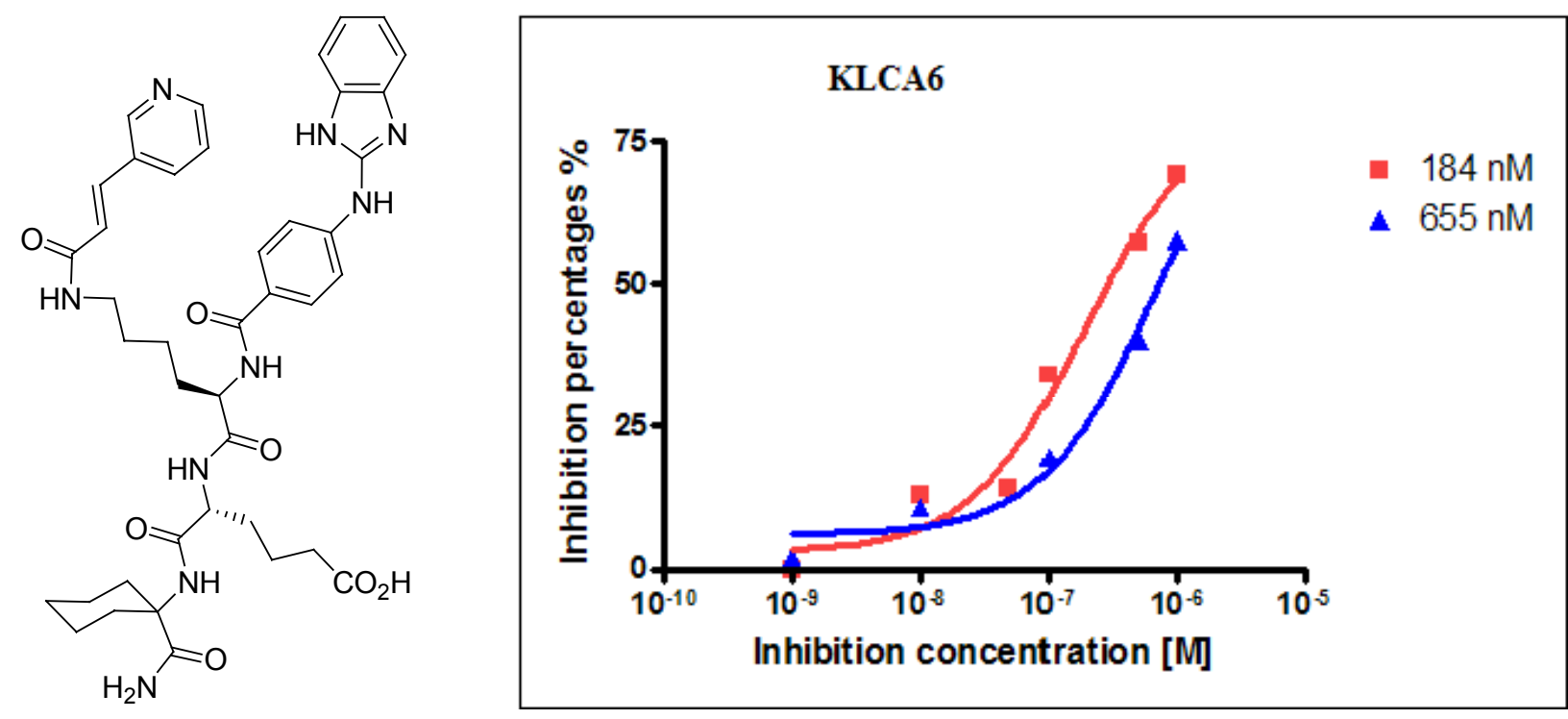

7: $\mathrm{IC}_{50}=419.5 \pm 333 \mathrm{nM}$
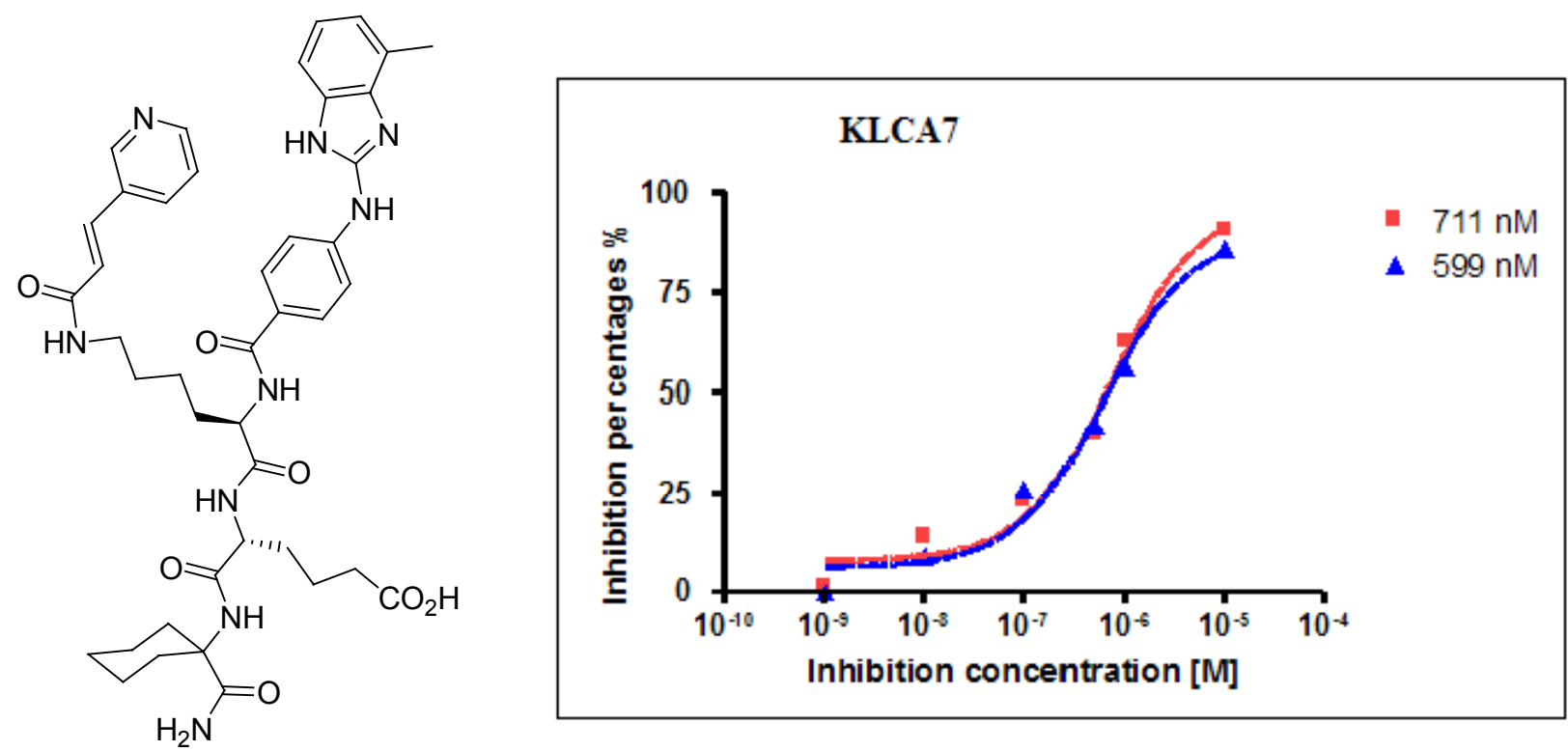

8: $\mathrm{IC}_{50}=655 \pm 79 \mathrm{nM}$ 

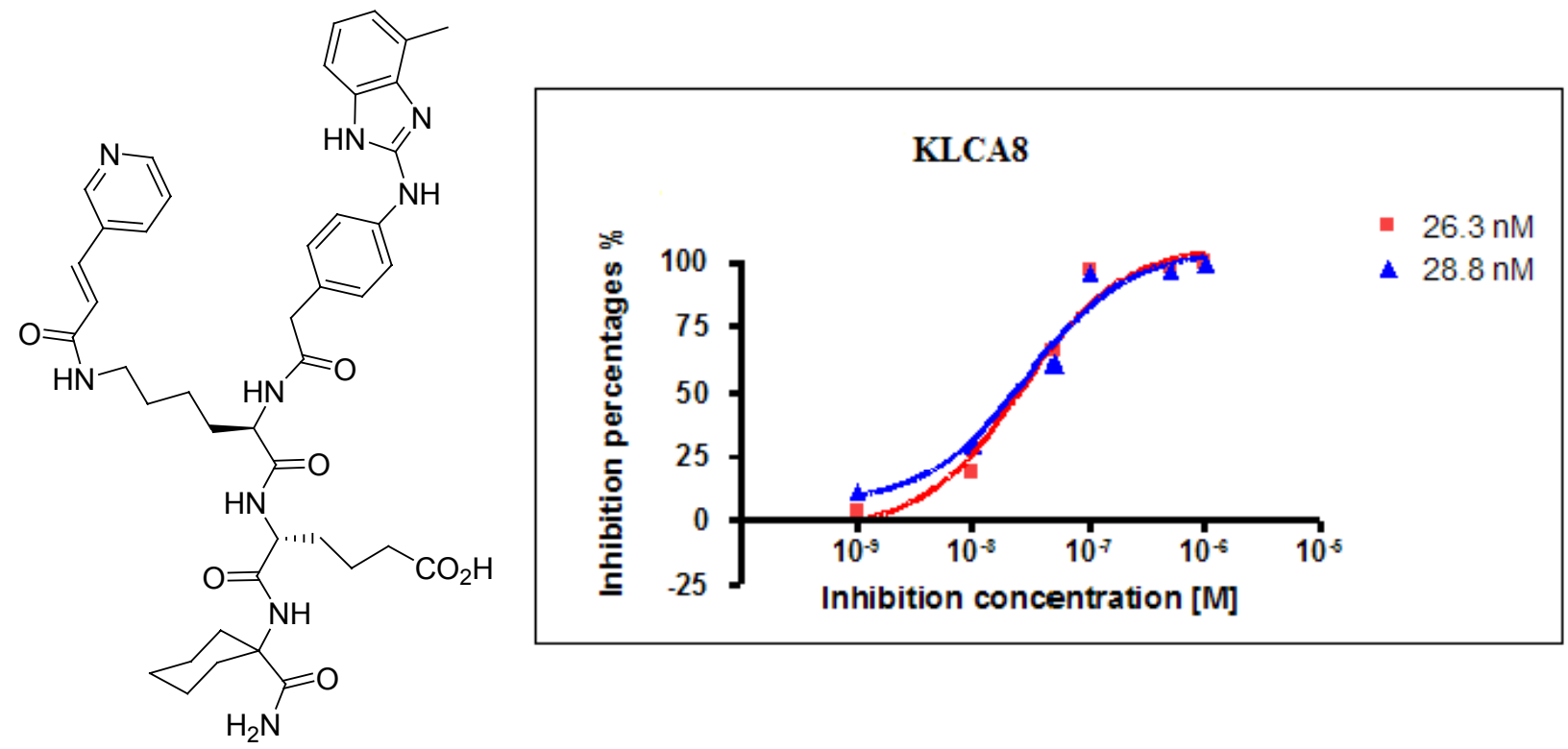

9: $\mathrm{IC}_{50}=27.5 \pm 1.76 \mathrm{nM}$
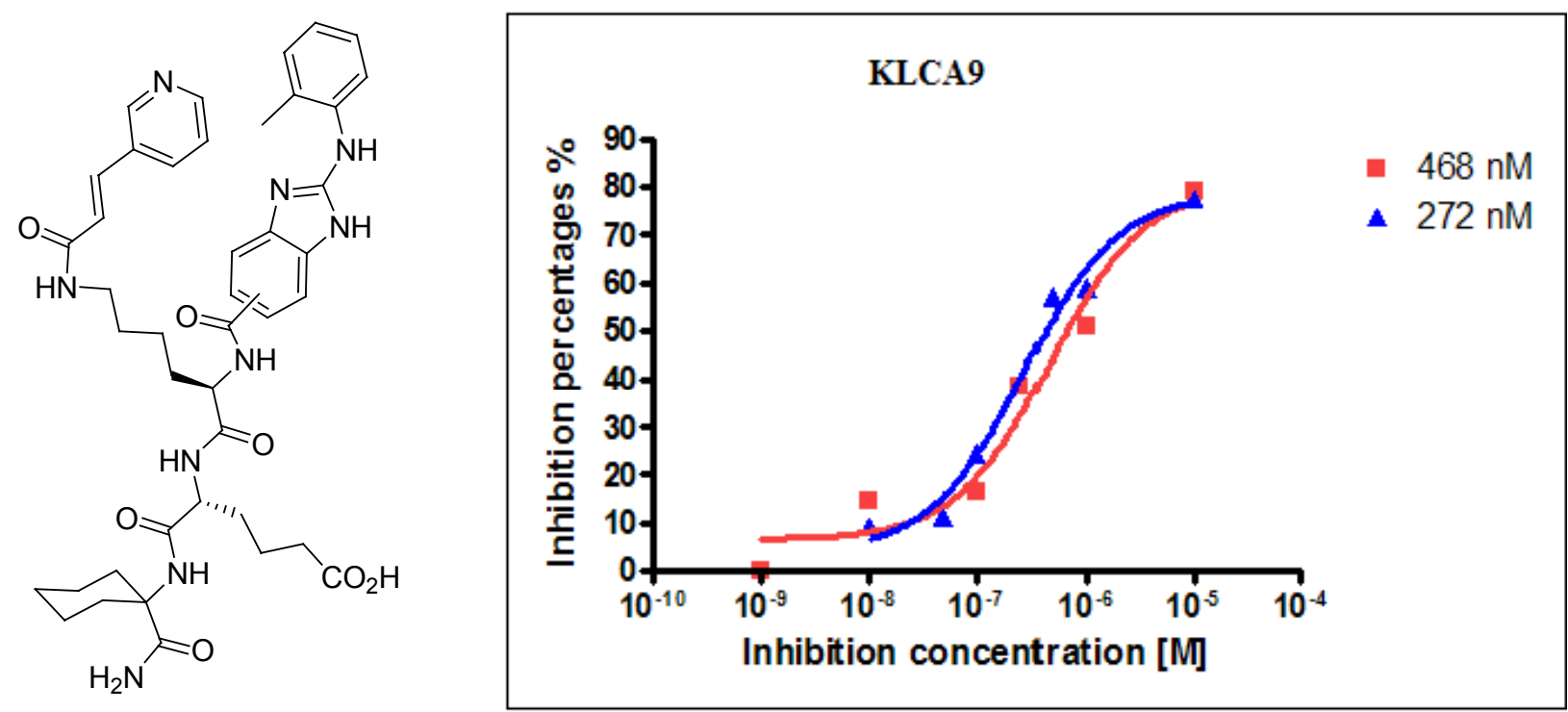

10: $\mathrm{IC}_{50}=379 \pm 138.5 \mathrm{nM}$ 